\title{
The Effect of Fix Up Strategy in Enhancing Students' Reading Comprehension in IAIN Curup
}

\author{
Hadi Suhermanto \\ IAIN Curup \\ hadi13nov74@gmail.com
}

\begin{abstract}
This study aimed to find out whether there is any effect of fix-up strategy on students' reading comprehension at second semester English Study Program students in IAIN Curup. This study employed a quasi experimental research design. The sample of this study was second semester English Study Program students in IAIN Curup. It consisted of 60 students. The instrument on this research was reading test which was aimed to measure students' reading comprehension. The reading test consists of 30 multiple choice questions for pre-and posttest. The finding of this research showed that the $\mathrm{t}$-count value was 3,905 more than t-table value, it means that $\mathrm{H}_{0}$ was rejected and hypothesis $\mathrm{H} 1$ that stated there was any effect of applying fix-up strategy on the students' reading comprehension at second semester English Study Program students in IAIN Curup was accepted. Fix-up strategy was proved to be effective to be used in teaching reading since there was a significant difference of students' meanscore after doing the treatment by using fix-up strategy.
\end{abstract}

Key words: Reading Comprehension, Fix-Up Strategy

\section{INTRODUCTION}

English is worldwide language that is learned by the entire nation in the world. Not only learned but also used as daily language for communicating with others or simply called English as a second language or English as foreign language. It is used to have interaction over the sea, technology literacy skill, and even to develop the knowledge. Someone must prepare her/himself with knowledge and 
skills in English language that are needed and suitable with world of work.

Reading is one of skills in English which is to make people get an information from what they read in order to be able to reach the comprehension. Reading is a fluent process of readers combining information from a text and their own background knowledge to build meaning. However, some people argue that comprehension is more difficult than just reading for understanding (Nunan, 2003). Actually, reading skill is very important for students such as; the students can get information from they read, the students can add their knowledge and can enlarge the way of their thinking by reading any text. Therefore, the students should have skill in reading to add their information and enrich their knowledge.

Reading comprehension is the core of the reading activity. By having comprehension, students are able to make sense what the texts tell about. Reading comprehension is as the process of simultaneously extracting and constructing meaning through interaction and involvement with written language (Catherine, 2002). They can also catch the general or detail information what the questions ask the students. Therefore, comprehension is the purpose of reading.

Nunan (2003) stated that there are eight principles of teaching reading, namely; exploit the reader's background knowledge, build a strong vocabulary base, teach for comprehension, work on increasing reading rate, teach reading strategies, encourage students to transform strategies into skills, build assessment and evaluation into your teaching and strive for continuous improvement as a reading teacher. Those principles will help the teacher to teach reading in order to help students reach the main goal of reading. That is comprehension.

Based on the researcher's experienceat second semester of English Study Program students in IAIN Curup on February, 2018,it was found that the students had a problem in reading. The students' reading comprehension was still low. It could be seen from the students' achievement reading score. There were more than half of students who got reading score under 70 . Moreover, there were some facts that indicated the problem. First, students' interest of reading was still low. Second, students had difficulties in understanding the text. They got it difficult in understanding sentences, finding the meaning of the sentences or only understood the broad outline of the text content. The students needed a lot of time in understanding the text, they did not use chance to read English text either at home or in English lesson. The students had difficulties in doing exercises. 
In teaching reading there are many strategies which can be applied by teachers such as: Selective Underlining, Anticipation Guide, Think Aloud Strategy, and fix-up strategy. All of those strategies are very important to improve teaching in learning process of English inclassroom in order to effective and efficient.One of effective strategies to be used in this school is fix-up strategy. Fix up strategy is a strategy which can help the students understand the message of the text when they get stuck with certain words or certain sentences.Morellion (2007: 116) says that fix up options are tools that readers can rely upon to find their way home, to make sense of what they read. When the students cannot understand the text during reading, the students use fix up option to catch the message of the text.

Duffy (209: 130) states that fix up strategy is frequently referred to as "look-backs." It refers to a strategy in which readers search backward and sometimes forward in a text to remove a meaning blockage encountered while reading. To use look-backs, reader's first need to understand that it is essential to monitor meaning getting what the reader reads, then to stophen a problem is encountered. Based on the problem above, the research question can be formulated as follow: is there any effect of applying Fix-Up strategy on students' reading comprehension at second semester English Study Program students in IAIN Curup?

\section{THEORITICAL FRAMEWORK}

\section{Definition of Reading}

Reading is one of skills in English to make readers get information from what they read, and information from a text, it needs a thinking process in order to be able to reach the comprehension. Reading is an extremely complex activity. It is involving combination of linguistics and cognitive abilities (Grabe \& Stoller, 2002). Relating linguistic abilities, reading involves the recognition of letters, words, phrases, and clauses. It also needs some aspects of language competences such as vocabulary, structure, spelling, and pronunciation. Meanwhile, in term of abilities, the view reading which is offered as essentially concerned with meaning, specifically with the transfer of meaning from mind to mind; the transfer of a message from writer to reader (Nuttall, 1982).

In preparing the students for having good ability in reading, teachers are demanded to be creative in using the variety of ways in teaching reading. Using interesting strategy in teaching reading will 
make students become motivated and active in learning process. Also teaching reading is prepared to make the students reach good comprehension of the lesson which is being taught. The goal of teaching reading is how to make students understand what they have read. Because of this case, reading is one activity of language skills that should be acquired by the students.

Reading is one of the important skills which should be achieved in learning English. There are some definitions of reading which are mentioned by the experts. Reading is a fluent process of readers combining information from a text and their own background knowledge to build meaning. In this case, the readers take the meaning from the text by combining information existed in the text and their experienced knowledge. In other words, it can be said that there is a correlation between the text and readers' background knowledge for understanding the meaning of the text read (Nuttal, 1982).

According to Snow (2002:54), "Reading comprehension is as theprocess of simultaneously extracting and constructing meaning throughinteraction and involvement with written language". In comprehendinga topic, the readers interacts with the text relates to the question of thetext to prior experiences of construct meaning which can be found in thetext. Reading comprehension is very important for everyone whowants to enlarge their knowledge and information. Therefore, in reading the readers should be active participants in catching the meaning from the text (Snow, 2002)

Based on the explanation of some experts above, it can be concluded that reading is an activity of communication process between the readers and written words for getting the ideas or information and derives meaning based on their own background knowledge. Based on the reading process, readers are hoped to get the understanding of the information which is talking in the text. The aim of reading is getting the comprehension of all information existed in the text read.

\section{Reading Comprehension}

For many students, reading is the act of saying word to their teacher and their friends by looking at the passage. They have not learned that reading is a division of the main idea between the author and them. Reading comprehension is a one of the complex and the combination of both lexical and text-progressing skills that are widely be acquainted interactively (Nunan, 2003). Two major approaches have been used to developing reading skill, known as extensive and intensive reading. These both approaches have important role play to gain knowledge in reading comprehension skill (Louky, 2003). 
According to Brassel et al (2008),before the students would learn how to comprehend their reading, the teacher should give definition what is reading comprehension and how they do to apply in learning process. Reading refers to the ability to comprehend or make meaning from written text.A dictionary definition of the word read states that it is the ability to examine and comprehend the meaning of written words. Comprehension, then, is at the heart of any conventional definition of reading. Comprehension is the process of deriving meaning from connected text (Elizabeth, 2003). It involves word knowledge (vocabulary) as well as thinking and reasoning. Therefore, comprehension is not a passive process, but an active one. The reader actively engages with the text to construct meaning.

This active engagement includes making use of prior knowledge. Comprehension is the essential goal of reading and reading instruction. Effective comprehension instruction goes beyond literal comprehension by challenging students to make deep inferences about texts, to think critically about the material they read, and to creatively transform the texts they encounter into other forms and formats. Moreover, effective instruction in comprehension should be engaging for students and teachers.

A great deal of research has explored and supported the notion that comprehension is a process demanding strategic approaches. Good comprehends have learned that they have control of the reading process. They actively construct meaning as they read, and they also direct their own comprehending(Blackhowic, 2008).

Reading comprehension is the activity where the students actually understand what they read about. Reading comprehension as the process of simultaneously extracting and constructing meaning through interaction and involvement with written language He uses the words extracting and constructing to emphasize both the importance and the insufficiency of thetext as a determinant of reading comprehension. Reading is an important activity in life with which one can update his or her knowledge. Reading skill is an important tool for academic success for students (Patel and Jain, 2008).

According to Snow (2002) Reading comprehension capacity builds on successful initial reading instruction and the fact that children who can read words accurately and rapidly have a good foundation for progressing well in comprehension-Reading comprehension involves much more than readers' responses to text. Reading comprehension is a multi component, highly complex process that involves many 
interactions between readers and what they bring to the text (previous knowledge, strategy use) as well as variables related to the text itself (interest in text, understanding of text types).

Furthermore, Reading comprehension is not a static competency; it varies according to the purposes for reading and the text that is involved. When the prerequisite skills are in place, reading becomes an evolving interaction between the text and the background knowledge of the reader (Louky, 2003).

\section{Comprehension Level}

Comprehension understands what is being said or read. When it comes to reading, it is an active process that must be developed if a learner is to become a proficient reader. Effective reading skill development is further accomplished when the learner becomes proficient in literal, inferential and critical comprehensive reading. Basaraba (2013) divided comprehension into three levels of comprehension, namely: literal, inferential, and evaluative level.

Literal comprehension involves what the author is actually saying. The reader needs to understand ideas and information explicitly stated in the reading material. Some of this information is in the form of recognizing and recalling facts, identifying the main idea, supporting details, categorizing, outlining, and summarizing. The reader is also locating information, using context clues to supply meaning, following specific directions, following a sequence, identifying stated conclusion, and identifying explicitly stated relationships and organizational patterns. These organizational patterns can include cause and effect as well as comparison and contrast. For example, some questions and activities may include: What words state the main idea of the story?, How does the author summarize what she/he is saying?.

Inferential comprehension deals with what the author means by what is said. The reader must simply read between the lines and make inferences about things not directly stated. Again these inferences are made in the main idea, supporting details, sequence, and cause and effect relationships. Inferential comprehension could also involve interpreting figurative language, drawing conclusions, predicting outcomes, determining the mood, and judging the author's point of view. The following questions are usually asked: What does the author value?, What is the theme?, What effect does this character/event have on the story?, How do you think this story will end?.

Evaluative comprehension is what the text is telling the readers about the world outside the story. Readers must analyze what they have read. Then they must form an opinion based on the information. In this 
levelof understanding of the text the reader can offer an opinion on the effectiveness of the text for its purpose.

The fix-up strategy will be effective to be used to improve students' literal, inferential, and evaluative comprehension.

\section{Definition of Fix-Up Strategy}

According to Duffy (2009), Fix up strategy is a strategy which can help the students understand the message of the text when they get stuck with certain words or certain sentences. When using this strategy the teachers should provide the students with some tools for fixing up their meaning-making. These tools are called fix up options. Morellion (2007) says that fix up options are tools that readers can rely upon to find their way home, to make sense of what they read. When the students cannot understand the text during reading, the students use fix up option to catch the message of the text. Duffy (2009) states that fix up strategy is frequently referred to as "lookbacks." It refers to a strategy in which readers search backward and sometimes forward in a text to remove a meaning blockage encountered while reading. To use look-backs, readers first need to understand that it is essential to monitor meaning getting as reader reads and that good readers stop when a problem is encountered.

Moreover, Moreillon (2007) states that fix-up strategy offers readers processes they can use to recover meaning, such as rereading, reading ahead, or figuring out unknown words. According to education.com, fix up strategy is a strategy used to reconstruct meaning when comprehension goes astray. Fix-up strategy includes rereading, reading ahead, identifying unknown words, making and changing predictions, connecting things in the text to personal experiences and memories.

\section{Steps in using Fix-Up Strategy}

The researcher will implement the procedures of teaching reading using fix-up strategy by adopting several steps according to Morellion (2007). The steps are as follows:

1. Previewing. The students are asked to look the text at glance. They preview and think what the text is about.

2. Predicting. The students read the heading or the title of the text and make a prediction what will happen next in the text.

3. Reading. The students are doing the activity in reading the whole text and check whether their prediction is correct or not.

4. Making connection.The students think about something that they have experienced which is related to the text. 
5. Visualizing. The students draw the characters which are stated in the text based on their imagination.

6.Making inference. The students make inference of what they read. It helps the students to sum up the important points of the text they read.

7.Asking new question and retelling the story. After reading the text, the students should ask questions related to the content of the text and retell what has been read to checkwhether they understand about the content or not.

\section{Previous Study}

There are some studies using Fix Up strategy. First, the research by Indrasari (2015) entitled "The Effectiveness of Using Fix-Up Strategy to Teach Reading Viewed From Students' Self-Confidence". Based on the result of data analysis, the research findings were: (1) Fix up strategy is more effective than direct teaching to teach reading; (2) the achievement of students' skill in reading does not depend on the level of the students' self-confidence; and (3) there is an interaction between teaching strategies and students' self-confidence.

Second, a research by Kusumawati (2019) entitled The Use of Fix Up Strategy in Teaching Reading Comprehension For Eleventh Grade Students at SMAN 7 Kediri. Thefindings of the research werethe t-test was higher than t-table $(7,539>2,034)$ it means that Ho was rejected and Ha was accepted. From the finding above, it can be concluded that Fix Up Strategy was effective used in teaching reading comprehension. The researcher suggests to the English teachers to teach the students using Fix Up strategy because it was suitable strategy which makes the students easier to comprehend the text in fix up options.

\section{RESEARCH METHODOLOGY}

This study employed a quasi experimental research design.. The researcher used fix-up strategy as an independent variable, in order students reading comprehesion as a dependent variable. The researcher used two groups: experimental and control group. Experimental group was a group that using Fix-Up strategy in teaching and learning process, while control group using conventional method. but, before give the treatment, a pre-test for each group given by the researcher in order to saw the level of students' qualifications. After the treatment, a post-test give both groups in order to know the students' reading comprehension scores.

The sample of this research was the second semester English Study Program students in IAIN Curup which consisted of 2 classes. The 
total number of sample was 60 students. The researcher decided to use some genres as the instrument of reading test based on the syllabus for second semester English students. The instrument was constructed by the researcher by collecting the questions from many sources, such as; book, worksheet, and internet.

In collecting the data, researcher did some procedure to execute this research. Both of the groups got a treatment in teaching but using different technique. Researcherconducted the research by giving the treatment both control and experiment group. For experiment group, the researcher used fix-up strategy, while for control group the researcher used conventional method in teaching reading which was usually used by the English lecturers in teaching writing descriptive text (which means no additional treatment for control group). The treatment was done in four meetings both experiment and control group. Then theresearcher gave some tests to know the students' scores in reading. The test was conducted in experimental class and control class.

The score of the test was given by the total of students' correct answer in test. Since this research is basically intend to investigate the effectiveness of using fix-up strategy toward reading comprehension. The data is obtain from the research use analyze Statistical Product for Service (SPSS) 17.0 in t- test formula to find out the significant difference and significant effect between the means and decide whether those differences are likely to happen by chance or by treatment effect. The researcher did the normality distribution and variance homogeneity test before calculated the data using t-test formula.

\section{FINDINGS \& DISCUSSIONS \\ Result}

After collecting and analyzing the data, the researcher displayed the result and findings in this chapter. The research question was answered and discussed detail in this chapter. The result of this research was divided into five sub-bab based on the data that was collected and analyzed by the researcher. Each sub-bab was described in detail below.

\section{Result of Normality and Homogeneity}

Before analyzing the hypothesis, the researcher did normality and homogeneity test. The normality test in this research used KolmogorovSmirnov of SPSS v.16 for windows with criteria $\rho>0.05$. Based on the calculation of normality, the researcher got the result that all data in pre-test both control and experiment class has been distributed 
normally. As the SPSS output showed that the sig. of pre-test on experiment and control class $=0,120$ and 0,200 which means that the data on pre-test both control and experiment class was normal. Furthermore, the sig. of post-test result on control and experiment class $=0,133$ and 0,122 which also means that the data was distributed normally on post-test.

Moreover, the output of homogeneity test shows that the significance of pre-test and post-test homogeneity result between both classes were 0,557 and 0,960 with $\mathrm{df} 2=58$. Since the sig. $>0,05$,it means that the sample of the data on pre-and post-test was homogenous. Since the data was distributed normally and homogenous, the researcher did independent sample t-test to examine the hypothesis.

\section{Result of the Study}

The results of this study were divided into two kinds, they were the result of pre-test (before giving the treatment) and the result of post-test (after giving the treatment).

\section{a. Result of pre-test}

The result of the pre-test was found before the researcher gave the treatment to the students both in experiment and control class. The result of the pre-test between control and experiment class did not different significantly. The result can be seen in the table below.

\section{Table 1}

The Meanscore of the Pre-Test

\begin{tabular}{|l|c|c|}
\hline Group & N & $\begin{array}{c}\text { Meansc } \\
\text { ore }\end{array}$ \\
\hline Experiment & 30 & 70.10 \\
Control & 30 & 69.43 \\
\hline
\end{tabular}

Table 1 showed that the mean score of experiment class was 70,01 with total sample was 30 students and the mean score of control class was 69,43 . Based on the result of the pre-test above, it can be seen that there was no significance difference of the students' mean score between experiment and control. It was because the students both experiment and control had similar cognitive achievement and competence in reading comprehension skill. The similar score between those groups became the reason why the researcher chose these two classes as the sample of this research. Therefore, to know whether Fixup strategy impact the students' reading comprehension, the researcher applied two different strategies. The researcher taught experiment class 
by using fix-up strategy while the researcher taught control class by using conventional method.

\section{b. Result of post-test}

After collecting the result of the pre-test, the researcher gave a treatment for control and experiment class. To find out the difference score between experiment and control class, the researcher gave a posttest to both experiment and control class. The post-test was given at the end of the treatment. The questions of post-test both experiment and control class was similar. After giving the post-test, the researcher calculated the score and mentioned it in the following table.

Table 2

The Meanscore of the Post-Test

\begin{tabular}{|l|r|r|}
\hline Group & $\mathbf{N}$ & Meanscore \\
\hline Experiment & 30 & 79.33 \\
Control & 30 & 69.76 \\
\hline
\end{tabular}

Regarding to table 2, the students' mean score of the experiment class in post-test was improved better from the pre-test score. While the score of post-test in control class did not show an improvement in posttest result. The improvement of students' score in experiment class from pre-test to post-test may be caused by the treatment did by the researcher. The researcher applied fix-up strategy in teaching reading in experiment group. However, to know whether the hypothesis was accepted or not, the researcher did hypothesis testing.

\section{Discussion}

The finding of this research showed that there was any effect of applying fix-up strategy on the students' reading comprehension at second semester of English Study Program Students of IAIN Curup. In other words, the use of fix-up strategy was generally more effective to improve students' reading comprehension.This research finding confirmed some theory and previous studies.

This study found that fix-up strategy is an efficient way to learn the course material in a cooperative learning approach which encourages engagement and empathy by giving each member of the group an essential part to play in the academic activity (Aronson, 2000). Fix up strategy is a strategy which can help the students understand the message of the text when they get stuck with certain words or certain sentences. When using this strategy the teachers should 
provide the students with some tools for fixing up their meaningmaking. These tools are called fix up options. Morellion (2007: 116) says that fix up options are tools that readers can rely upon to find their way home, to make sense of what they read. When the students cannot understand the text during reading, the students use fix up option to catch the message of the text. Duffy (209: 130) states that fix up strategy is frequently referred to as "look-backs." It refers to a strategy in which readers search backward and sometimes forward in a text to remove a meaning blockage encountered while reading. To use look-backs, readers first need to understand that it is essential to monitor meaning getting as reader reads and that good readers stop when a problem is encountered.

Moreover, Moreillon (2007: 114) states that fix-up strategy offers readers processes they can use to recover meaning, such as rereading, reading ahead, or figuring out unknown words. According to education.com, fix up strategy is a strategy used to reconstruct meaning when comprehension goes astray. Fix-up strategy includes rereading, reading ahead, identifying unknown words, making and changing predictions, connecting things in the text to personal experiences and memories.

\section{CONCLUSION \& SUGGESTION \\ Conclusion}

Regarding to the finding of this research, it can be concluded that there was a significant effect of applying fix-up strategy on the students' reading comprehension at second semester of English Study Program Students of IAIN Curup. In other words, the use of fix-up strategy was generally effective to improve students' reading comprehension at second semester of English Study Program Students of IAIN Curup.

\section{Suggestion} followings:

There are some suggestions offered by the researcher to the

1. Special for English teacher, fix-up strategy is one of teaching technique that can be considered to improve the students' reading competence in the classroom especially in reading text. Therefore, it is expected for the teacher/lecturers to encourage the students in reading activity in the classroom.

2. The use of fix-up strategy is useful to organize the students' reading comprehension. The teacher's guidance while teaching and learning was needed to get better achievement. 
3. More research studies with EFL readers should be executed to further investigate the effectiveness of fix-up strategy on reading comprehension.

\section{REFERENCES}

Airasian, P and L. R. Gay. 2004. Educational Research: Competencies for Analysis and Application Sixth Edition. New Jersey: Prentice Hall Inc.

Arikunto,Suharsimi. (2006). Prosedur penelitian (suatu pendekatan praktis. Jakarta: Rineka Cipta.

Blackhowic. (2008). Reading comprehension: strategies for independent learners: Second Edition. New York: The Guilford Press.

Basaraba. 2013. Examining the Structure of Reading Comprehension: Do Literal, Inferential, and Evaluative Comprehension Truly Exist?. https://eric.ed.gov/?id=EJ998201

Brassell, Danny, et all. (2008). Comprehension that works: taking students beyond ordinary understanding to deep comprehension . Huntington Beach: Corrine Burton.

Catherine. (2002). A Practical Guide to Research Methods, How To Content, Oxford

Cohen, Louis,. et al. 2007. Research Method in Education. New York: Routledge

Desti. (2008). Teaching reading using POSSE (Predict, Organize, Search, Summarize, Evaluate) strategy. Unpublished thesis

Duffy, Gerald G. 2009. Explaining Reading : A Resource for Teaching Concepts, Skills, and Strategies. New York: The Guildford Press.

Elliot, Stephen N. et at. 2000. Educational Psychology: Effective Teaching, Effective Learning. Boston: The McGraw-Hill Companies, Inc.

Elizabeth. (2003). Teaching \& learning in the language classroom. UK: OUP.

Grabe, W. And Stoller, F.L. (2002). Teaching and researching reading. Harlow: Pearson Education.

Iskandar. (2009). Metodologi penelitian pendidikan dan sosial (kuantitatif dan kualitatif). Jakarta: GP Press. 
Julian Hermida. (2001). The what, why and how of classroom action research. JoSoTL Vol. 2, Number 1.

J. F. Baumann, L. A. Jones, N. S. Kessel. Using think aloud to enhance children's comprehension monitoring abilities. The Reading Teacher, 47(3), 184-193, 1993.

Kushartini. 2005. Pesona Bahasa. Jakarta: PT. Sun Printing

Lems, et al. (2010). Teaching reading to english language learners insights from linguistics. New York: The Divison of Guiford Publications, Inc.

Lindsay, Jeff. 2012. Direct Instruction: Proven Success in Teaching. Retrieved from http://www.jefflindsay.com/EducData.shtml.

Loucky, J. P. (2003): Enhancing students' English reading and vocabulary skills using CALL innovations. Seinan Women's University, Tandai Kiyo, Vol. 49.

Mckeown, R. G., \& Gentilucci, J. L. (2007). Think-Aloud strategy: Metacognitive development and monitoring comprehension in the middle school second-language classroom. Journal of Adolescent \& Adult Literacy, 51(2), 136-147.

Moreillon, J. 2007. Collaborative Strategies forTeaching Reading Comprehension. Chicago: American Library AssociationNunan, David. 2003. Language Teaching Methodology. London: Prentice HallInternational

Moss, B. (2005). Making a case and a place for effective content area literacy instruction in the elementary grades. The Reading Teacher, 59(1), 46-55. doi:10.1598/RT.59.1.5

Nunan, David. (2003). Practical English language teaching. New York:The McGraw-Hill Companies,Inc.

Oster, L. (2001). Using the think-aloud for reading instruction. The Reading Teacher, 3, 64-69.

Oxford. (2006). Word Power Dictionary(pp 717). New York: Oxford University press.

Patel and Jain. (2008). English language teaching: methods, tools, and technique. New York:Sunrise Publisher and Distribution.

Prezler, J. (2006). Strategies to Help Readers Make Meaning through Inferences Grade 4-12. (pp 4). South Dakota Department of Education

Seyler, Dorothy U. (2004). The readingcontext: developing college reading skills. New York :Pearson Education, Inc.

Wade, S. (1990). Using think aloud to assess comprehension. The Reading Teacher, 3, 86-94. 